\title{
A 23-Year Follow-Up of a Patient with Gain-of-Function IkB-Alpha Mutation and Stable Full Chimerism After Hematopoietic Stem Cell Transplantation
}

\author{
Francesca Conti $^{1}$ • Rita Carsetti ${ }^{2}$ - Jean-Laurent Casanova ${ }^{3,4,5,6,7}$ • Alain Fischer ${ }^{5,6,8,9}$ - Caterina Cancrini ${ }^{1,10}$
}

Received: 13 September 2019 / Accepted: 31 March 2020 / Published online: 2 July 2020

(C) Springer Science+Business Media, LLC, part of Springer Nature 2020

Keywords Follow-up $\cdot$ HSCT $\cdot \mathrm{IkB} \alpha \cdot$ ED-ID $\cdot$ epidermodysplasia verruciformis

\begin{tabular}{|c|c|}
\hline Abbreviations & \\
\hline AD ED-ID & $\begin{array}{l}\text { Autosomal dominant ectodermal } \\
\text { dysplasia with immune deficiency }\end{array}$ \\
\hline APC & Antigen presenting cells \\
\hline $\mathrm{CT}$ & Computed tomography \\
\hline $\mathrm{EV}$ & Epidermodysplasia verruciformis \\
\hline HPV & Human papillomavirus \\
\hline HSCT & Hematopoietic stem cell transplantation \\
\hline IVIG & $\begin{array}{l}\text { Intravenous immunoglobulin } \\
\text { replacement therapy }\end{array}$ \\
\hline LTo & Lymphoid tissue organizer \\
\hline NEMO & Nuclear factor $\mathrm{\kappa B}$ essential modulator \\
\hline NF-kB & $\begin{array}{l}\text { Nuclear factor kappa-light-chain-enhancer } \\
\text { of activated B cells }\end{array}$ \\
\hline TCR & $\mathrm{T}$ cell receptor \\
\hline SCID & Severe combined immunodeficiency \\
\hline XR-EDA-ID & $\begin{array}{l}\text { X-linked recessive ectodermal dysplasia } \\
\text { with immunodeficiency }\end{array}$ \\
\hline
\end{tabular}

Caterina Cancrini

caterina.cancrini@opbg.net; cancrini@med.uniroma2.it

1 University Department of Pediatrics, Unit of Immune and Infectious Diseases, Childrens' Hospital Bambino Gesù, Piazza S. Onofrio 4, Rome, Italy

2 Unit of Diagnostic Immunology, Department of Laboratories, Bambino Gesù Children's Hospital, IRCCS, Rome, Italy

3 St. Giles Laboratory of Human Genetics of Infectious Diseases, Rockefeller Branch, The Rockefeller University, New York, NY 10065, USA

4 Laboratory of Human Genetics of Infectious Diseases, Necker Branch, INSERM U1163, 75015 Paris, France
To the Editor:

Hypermorphic mutations in inhibitor $\alpha$ of transcription factor NF-kB (nuclear factor kappa-light-chain-enhancer in activated $\mathrm{B}$ cells) $(\mathrm{I} \kappa \mathrm{B} \alpha)$, encoded by the NFKBIA gene, cause autosomal dominant ectodermal dysplasia with immune deficiency (AD ED-ID) [1, 2]. Eleven out of fourteen reported patients underwent allogenic hematopoietic stem cell transplantation (HSCT) [1]. Here we describe the 23-year followup after HSCT in the first reported NFKBIA mutated patient, who presented with severe combined immunodeficiency (SCID) at 6 months of age [2]. Due to severe clinical presentation and marked immunologic abnormalities, despite the unknown genetic origin of the disease, HSCT was performed at 1 year of age [3]. The child received a $\mathrm{T}$ cell depleted graft from his haploidentical mother preceded by a conditioning regimen consisting of busulfan and cyclophosphamide. The molecular diagnosis of EDA-ID was made at 3 years of age when EDA features associated with immunodeficiency became apparent. We found a gain of function de novo point mutation in NFKBIA (p.S32I). The early post-HSCT period was without major complications. A full donor chimerism was

5 Imagine Institute, Paris Descartes University, 75015 Paris, France

6 Pediatric Immunology, Hematology, and Rheumatology Unit, Hopital Necker Enfants-Malades, Assistance Publique-Hôpitaux de Paris, 75015 Paris, France

7 Howard Hughes Medical Institute, New York, NY 10065, USA

8 Collège de France, Paris, France

9 INSERM U1163, 75015 Paris, France

10 Department of Systems Medicine, University of Rome Tor Vergata, Rome, Italy 
observed over time [3]. At his most recent follow-up, 21 years after HSCT, the patient appeared in overall good general conditions; however, he had experienced a variety of infectious and non-infectious diseases (Fig. 1). He continued to suffer from recurrent upper and lower respiratory tract infections including three episodes of pneumonia requiring hospitalization and a bilateral bacterial otomastoiditis. He had bronchiectasis involving all lung fields at chest computed tomography (CT) scan and pulmonary function tests showing a mild to moderate obstructive ventilatory failure. Occasionally, he showed an exacerbation of pulmonary symptoms associated with the isolation from sputum of Pseudomonas aeruginosa, Haemophilus influenzae, and Staphylococcus aureus which needed periodically selective decontamination with antibiotic therapy. Moreover, he developed chronic sinusitis and nasal polyposis requiring surgical curettage. During the 5 -year period from 2003 to 2008 (when he was 7-12 years old), the patient experienced three episodes of herpes zoster infection. Since the age of 7 years, flat warts appeared behind the ears and the forehead. The lesions worsened over time spreading on the whole body surface. He was treated with cycles of topic retinoic acid and imiquimod with slight and transitory improvement. Because of lack of clinical remission, he underwent a treatment with cidofovir (once a week for 8 weeks) and IFN- $\alpha$ ( 3 times weekly), obtaining a partial and short-term improvement of skin lesions. Biopsies were repeated during follow-up, showing verruca plana-like lesions with mild hyperkeratosis, hypergranulosis, and acanthosis of the epidermis. Keratinocytes of the upper epidermal layers were enlarged with perinuclear vacuolization. Stratum corneum displayed basket weave-like pattern. Identification of $\beta$-human papillomavirus (HPV)-151 species was obtained through PCR amplification [4]. The patient remained on intravenous immunoglobulin replacement therapy (IVIG) until 7 years of age when therapy was discontinued based on improved clinical conditions, normal Ig values, and protective titres against vaccines. Subsequently, the patient experienced a sepsis due to Klebsiella pneumoniae and exacerbation of chronic sinusitis. Therefore, Ig replacement therapy was reinstituted based on clinical course, a rapid decrease of specific antibodies titres against Streptococcus pneumoniae nonconjugated vaccine, indicating altered specific memory response [3] and alterations in B cell maturation (Figs. 2, 3 and 4). Currently, the patient is still on replacement therapy and cyclic antibiotic prophylaxis. Non-infectious complications accounted for 2 episodes of aseptic meningitis following IVIG infusion at 4 and 5 years of age, and we observed an isolated inflammatory coxo-femoral arthritis at the age of 4 years which responded to a short course of steroids. During follow-up, we observed a fluctuating and mild increase of liver function tests often associated with drug administration and/or acute events persisting overtime. Extensive laboratory work-up on suspicion of a liver chronic disease showed normal liver function and levels of alpha-fetoprotein, amylase, lipase, alkaline-phosphatase, $\alpha 1$ antitrypsin, and ceruloplasmin.

Ultrasound scan of the abdomen disclosed normal organ size and slightly increased liver echogenicity, not dilated bile ducts. Percutaneous liver biopsy (Fig. 5) showed minimal histological abnormalities, described as ductular focal metaplasia
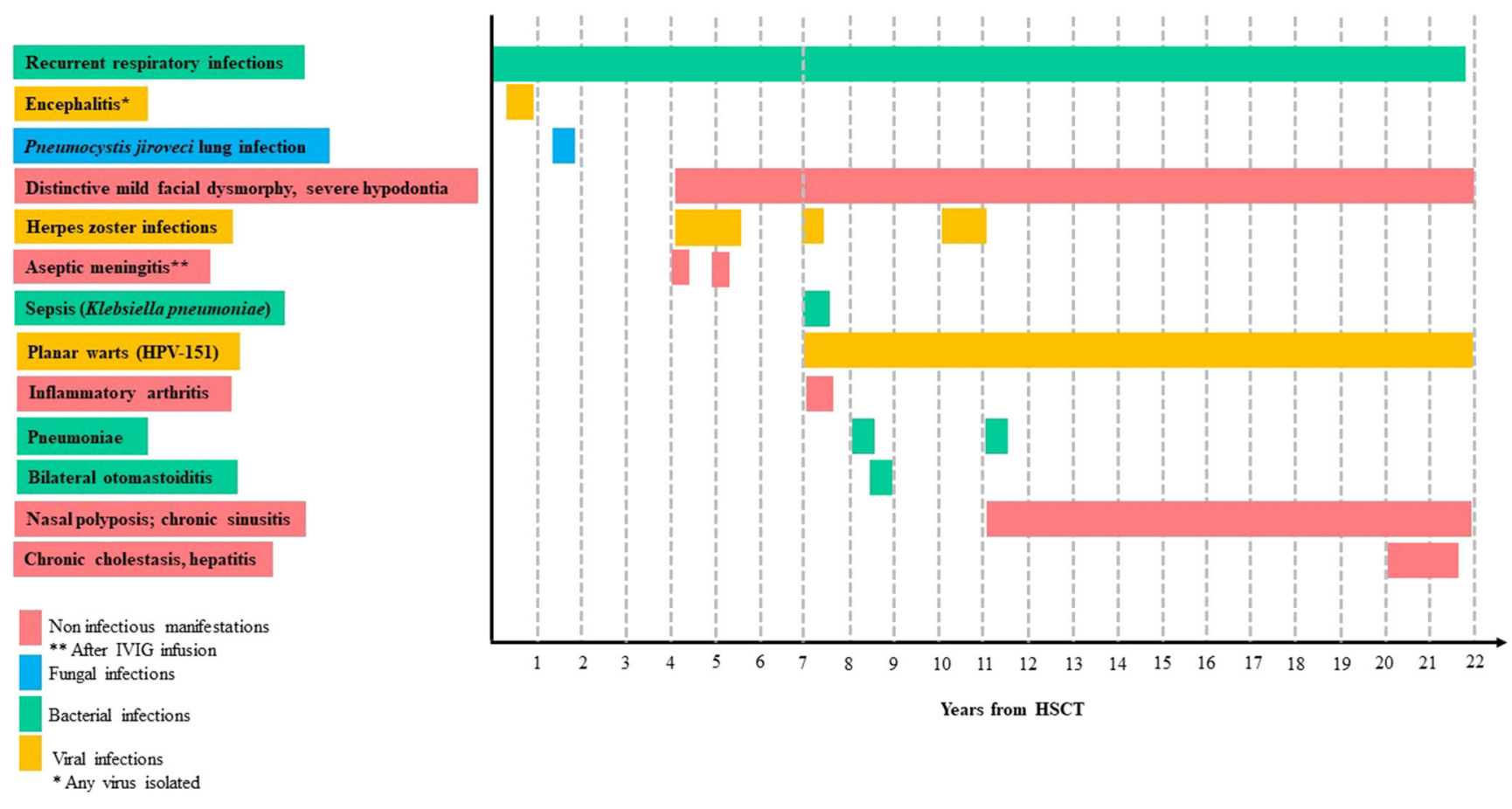

Fig. 1 Clinically significant events after HSCT 
UNT

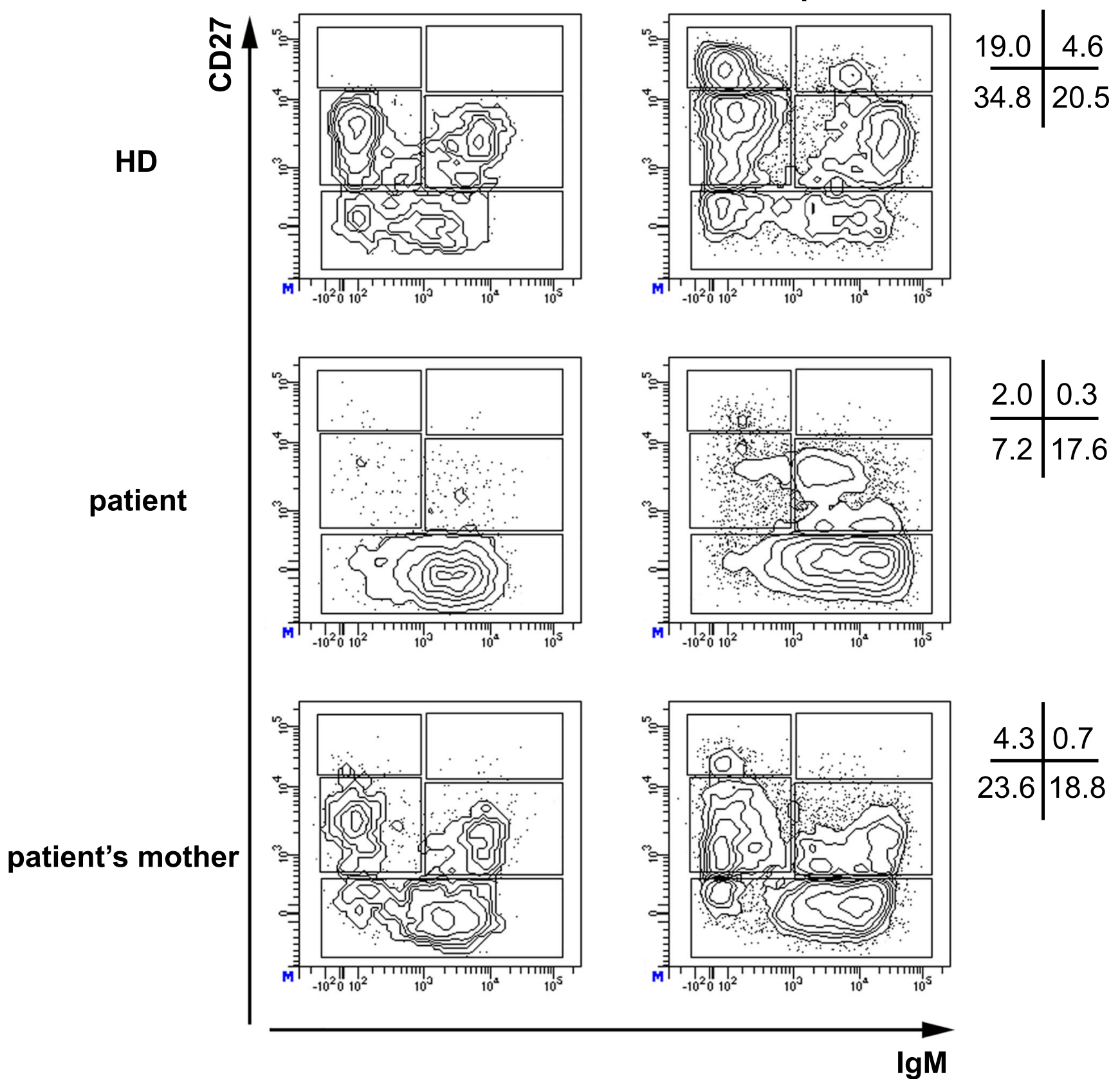

Fig. 2 TLR-9 response from healthy control, patient, and patient's mother. Contour plots show the staining of B cells in the absence (UNT) or presence of CpG. The gates identify the different B cell populations: IgM+ and IgM- CD27++ plasma cells, CD27+ memory B cells

suggestive of minimal cholangiopathy. Hepatotropic viruses (HCV, HBV, CMV, EBV, Adenovirus, HHV-6, BK virus, and JC virus) and specific liver autoimmunity (ANA, ANCA, ASMA, LKM, LC1, ARA, AMA, and APCA) resulted negative. Patient growth pattern remained at the 3rd percentile for weight and 3rd to 10th for height, much lower than that are either IgM memory (IgM+) or switched memory (IgM-), and mature-naive B cells. The numbers indicate the percentage of IgM - and IgM+ CD27++ plasma cells, IgM- CD27+ memory B cells (switched), and IgM memory B cells (B cells gate)

the predicted target height, estimated at $182-198 \mathrm{~cm}$ (90th97th percentile); normal pubertal development was recorded. Regular school attendance was achieved. Comprehensive serial immunological evaluation showed stable, full, heterologous chimerism in $\mathrm{T}$ cells, B cells, and monocytes, a progressive normalization of total lymphocytes count, memory/naive 


\section{Lymphocytes gate}

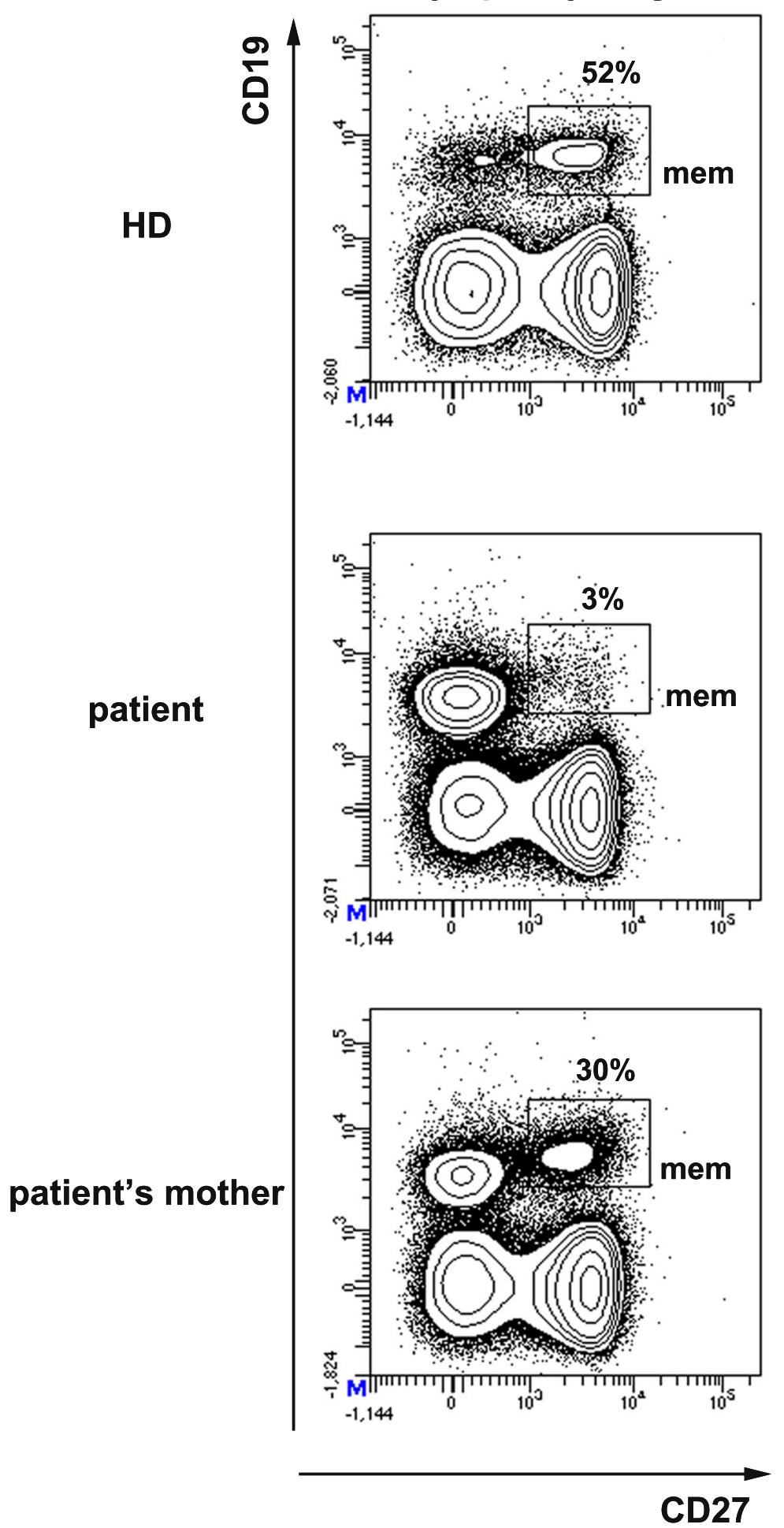

B cells
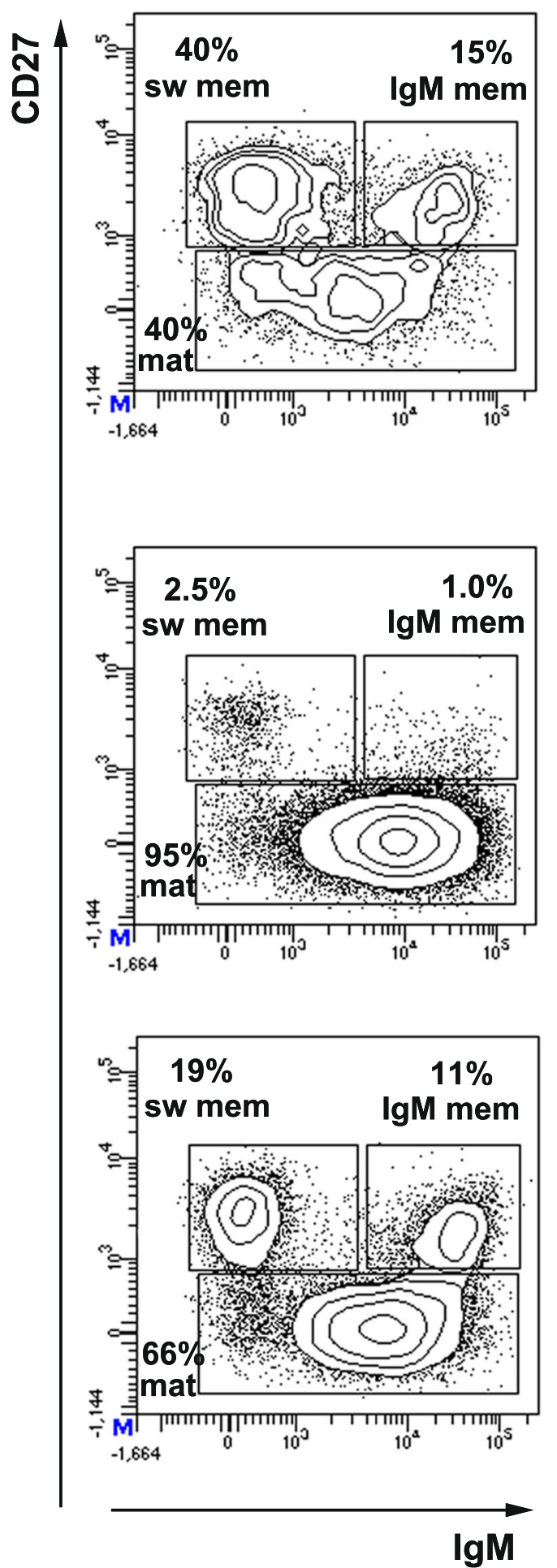

Fig. 3 B cell phenotype. Contour plots show B cells from healthy control, patient, and patient's mother. Memory B cells (mem) are identified as $\mathrm{CD} 19+\mathrm{CD} 27+$ (in the lymphocyte gate). CD19+ B cells can be distinguished into mature-naive $\mathrm{B}$ cells $(\mathrm{CD} 27-$ and $\mathrm{IgM}+$ ), switched memory $\mathrm{B}$ cells (CD27+ and IgM-), and IgM memory B cells (CD27+ and IgM+).
The numbers indicate the percentage of total memory (left plots), mature, switched, and IgM memory (right plots) B cells. Normal values for B cell subsets: total memory (17.5-46.5), mature (48.4-79.7), switched (8.327.8), and IgM memory (7.0-23.8) from Piatosa B et al., Cytometry Part B (Clinical Cytometry) 2010 
Fig. 4 Immunoglobulin concentration in healthy control, patient, and patient's mother. The histograms show the concentration (microgram $/ \mathrm{ml}$ ) of immunoglobulins IgM, IgA, and IgG produced in response to the stimulation of PBMCs with $\mathrm{CpG}$. Normal values are calculated from 15 healthy controls. Unstimulated PBMCs: IgM (0.001-0.201); IgA $(0.001-$ $0.276)$; and IgG (0.001-0.13). CpG stimulated PBMCs: IgM (0.432-7776); IgA (0.048-

3.588); and $\operatorname{IgG}(0.12-3.159)$

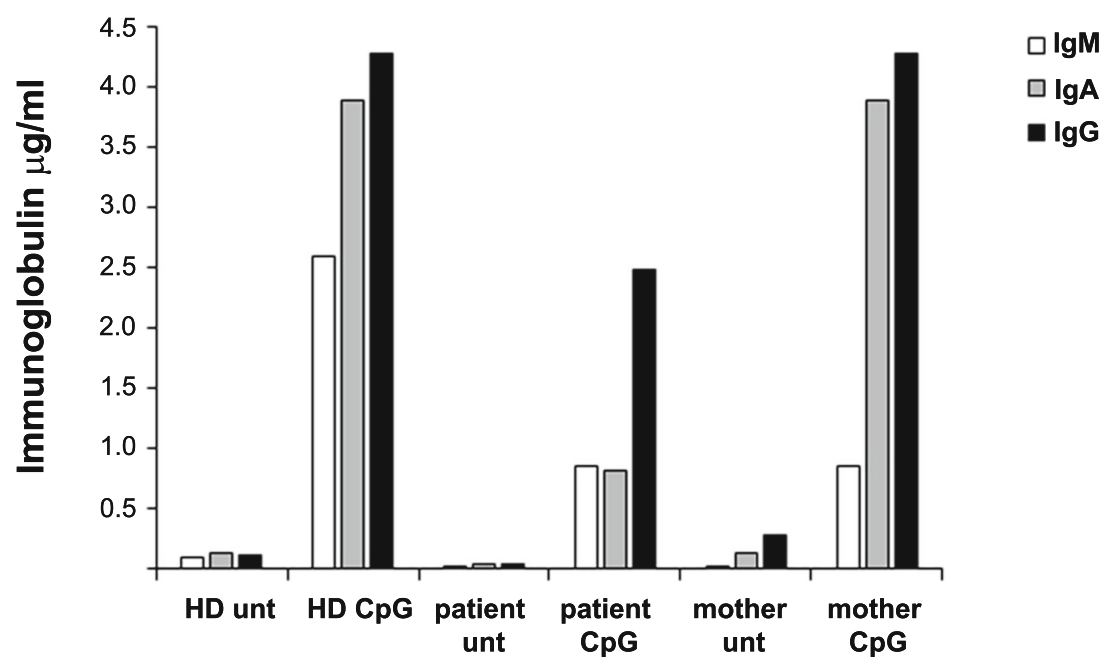

ratio, $\mathrm{T}$ lymphocytes proliferation (Table 1), and polyclonal $\mathrm{T}$ cell receptor (TCR) profile on CD4+ and CD8+ [3] (data not shown). Despite normal CD19+ B cells count which were $100 \%$ maternal-derived, abnormalities in B cell maturation with low memory B cells (CD19CD27+) were observed over time. Switched B cells (CD19+27+IgM-IgD-) were absent whereas IgM memory B cells were detectable. In agreement with the phenotype, upon $\mathrm{CpG}$ stimulation, low proliferation and differentiation of $\mathrm{B}$ cells, absence of switched plasma cells, and isotype switch to $\operatorname{IgG} / \operatorname{IgA}$ were obtained. Maternal PBMCs, in contrast, had normal B cell phenotype and in vitro proliferation and differentiation (Figs. 2, 3, and 4). These data and the absence of lymphatic tissues (tonsils and lymph nodes) in the patient led to the hypothesis that the persistent immune deficiency might be caused by the underlying micro-environmental disorder due to the NFKBIA mutation. As reported in mutant mice, a greater impairment of canonical and non-canonical NF-kB activity and a more severe phenotype in patients with $\mathrm{I} \kappa \mathrm{B} \alpha$ point mutations compared with truncation mutants lead to significantly diminished CCL20, ICAM1, and VCAM1 expression, crucial for lymphoid tissue organizer (LTo) cell functions and lymphoid organogenesis $[1,5,6]$. Moreover, the persistence of epidermodysplasia verruciformis (EV)-like syndrome due to
$\beta$-HPV, despite full donor chimerism, might be explained by an impaired NF-kB signaling in extra-hematopoietic cell responses (intrinsic keratinocytes defect), as reported in transplanted patients with gamma-chain or Janus kinase 3 (JAK-3) deficiency [7, 8]. Another plausible explanation might be an impaired innate immune activation due to defective antigen presenting cells (APC) presentation limiting the restoration of a complete immunological function. Genetic causes of EV have been identified and classified as classical (EVER1, EVER2, and CIB1) and non-classical (T cells defect), the former impairing keratinocyte-intrinsic immunity and underlying the selective susceptibility to $\beta$-HPVs [9]. Currently, none inborn errors of NF-kB pathway have been observed in association with skin lesions caused by $\beta$-HPVs [10]. We describe the first clinical and immunologic long-term follow-up after HSCT of a patient with a hypermorphic mutation in NFKBIA. The severe immunodeficiency with lifethreatening infections justified the approach of haploidentical HSCT. Transplantation resulted in a long-lasting clinical improvement, which was, however, associated with a persistent susceptibility to bacterial and viral infections and residual immunological defects. The case described shows that HSCT represents a life-saving treatment option to correct severe immunological defect in $N F K B I$-mutated patients but
Fig. 5 Patient skin punch biopsy (hematoxylin and eosin stain). a $(\mathrm{HE} \times 10)$. b $(\mathrm{HE} \times 20)$. Verruca plana-like lesions with mild hyperkeratosis, hypergranulosis, and acanthosis of the epidermis. Keratinocytes of the upper epidermal layers were enlarged with perinuclear vacuolization. Stratum corneum displayed basket weave-like pattern
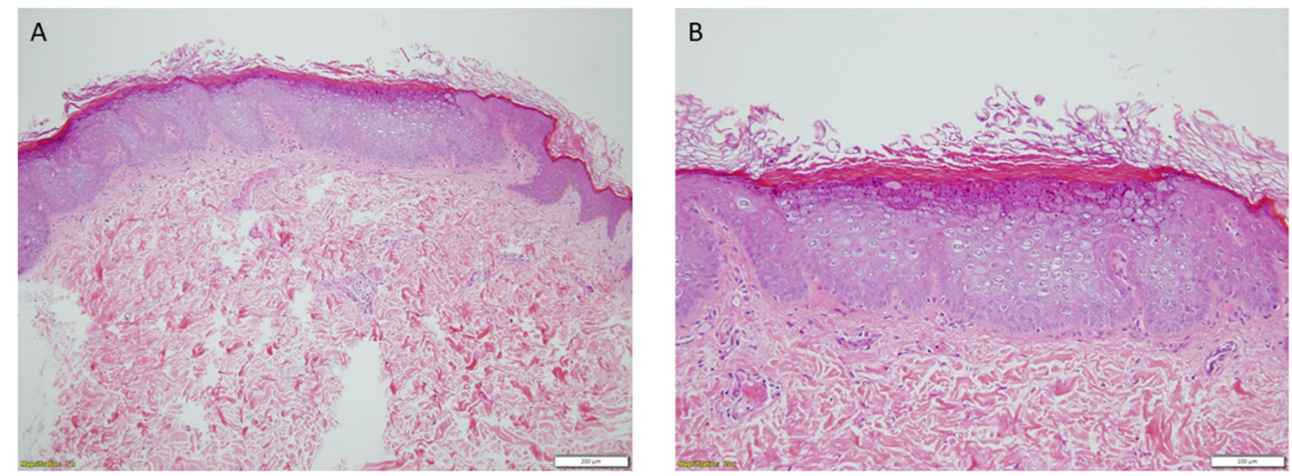
Table 1 Immunologic data before and after HSCT

\begin{tabular}{|c|c|c|c|c|c|c|}
\hline \multicolumn{7}{|l|}{ Parameter } \\
\hline Sex & Male & & & & & \\
\hline Age & 22 years & & & & & \\
\hline Age at diagnosis & 3 years & & & & & \\
\hline Parameter & $\begin{array}{l}\text { Age } 9 \text { months } \\
\text { (before HSCT) }\end{array}$ & $\begin{array}{l}\text { Age } 4 \text { years } \\
\text { (3 years after } \\
\text { HSCT) }\end{array}$ & $\begin{array}{l}\text { Age } 8 \text { years } \\
\text { (7 years after } \\
\text { HSCT) }\end{array}$ & $\begin{array}{l}\text { Age } 12 \text { years } \\
\text { (11 years after } \\
\text { HSCT) }\end{array}$ & $\begin{array}{l}\text { Age } 19 \text { years } \\
\text { (18 years after } \\
\text { HSCT) }\end{array}$ & $\begin{array}{l}\text { Age } 22 \text { years } \\
\text { (21 years after } \\
\text { HSCT) }\end{array}$ \\
\hline White blood cells, $10^{\wedge} 3 / \mathrm{uL}$ & 29.4 & 21.00 & 17.87 & 12.34 & 9.65 & 12.49 \\
\hline Hemoglobin, $g / L$ & 10.5 & 11 & 13.9 & 14 & 15.7 & 15.9 \\
\hline Platelets, $10^{\wedge} 3 / \mathrm{uL}$ & 528 & 450 & 357 & 300 & 245 & 256 \\
\hline \multicolumn{7}{|c|}{ Serum immunoglobulin levels, mg/L } \\
\hline IgG & $\begin{array}{l}<1 \\
(421-1100)\end{array}$ & $\begin{array}{l}890 * \\
(539-1200)\end{array}$ & $\begin{array}{l}560 * \\
(527-1590)\end{array}$ & $664^{*}$ & 940 & $\begin{array}{l}740 * \\
(830-1820)\end{array}$ \\
\hline IgA & $\begin{array}{l}11 \\
(18.4-154.0)\end{array}$ & $\begin{array}{l}44 \\
(40.7-115.0)\end{array}$ & $\begin{array}{l}85 \\
(36.1-268.0)\end{array}$ & 42 & 43 & $\begin{array}{l}66 \\
(46.5-221.0)\end{array}$ \\
\hline IgM & $\begin{array}{l}26 \\
(23.5-180.0)\end{array}$ & $\begin{array}{l}68 \\
(26.1-188.0)\end{array}$ & $\begin{array}{l}43 \\
(30.5-220.0)\end{array}$ & 48 & 73 & $\begin{array}{l}55 \\
(75.0-198.5)\end{array}$ \\
\hline IgG1 & ND & ND & 460 & ND & ND & 590 \\
\hline IgG2 & ND & ND & 80 & ND & ND & 100 \\
\hline IgG3 & ND & ND & 10 & ND & ND & 40 \\
\hline IgG4 & ND & ND & 10 & ND & ND & 10 \\
\hline \multicolumn{7}{|l|}{ Lymphocyte phenotype } \\
\hline Lymphocytes, $10^{\wedge} 3 / \mathrm{uL}$ & $\begin{array}{l}22.9 \\
(3.2-12.3)\end{array}$ & $\begin{array}{l}14.00 \\
(1.4-5.5)\end{array}$ & $\begin{array}{l}12.73 \\
(1.2-4.7)\end{array}$ & $\begin{array}{l}8.06 \\
(1.2-4.7)\end{array}$ & $\begin{array}{l}5.21 \\
(1.2-4.1)\end{array}$ & $\begin{array}{l}5.86 \\
(1.2-4.1)\end{array}$ \\
\hline $\mathrm{CD} 3, \%(\mathrm{cells} / \mu \mathrm{L})$ & $\begin{array}{l}77(17633) \\
(2.4-8.3)\end{array}$ & $\begin{array}{l}73(10220) \\
(0.85-4.3)\end{array}$ & $\begin{array}{l}67(8529) \\
(0.77-4.0)\end{array}$ & $\begin{array}{l}65 \\
(0.85-3.2)\end{array}$ & $\begin{array}{l}65 \\
(0.78-3.0)\end{array}$ & $\begin{array}{l}65(3809) \\
(0.78-3.0)\end{array}$ \\
\hline CD4, \% (cells $/ \mu \mathrm{L})$ & $\begin{array}{l}55(12595) \\
(1.3-7.1)\end{array}$ & $\begin{array}{l}39(5460) \\
(0.5-2.7)\end{array}$ & $\begin{array}{l}37(4710) \\
(0.4-2.5)\end{array}$ & $\begin{array}{l}35 \\
(0.4-2.1)\end{array}$ & $\begin{array}{l}37 \\
(0.5-2.0)\end{array}$ & $\begin{array}{l}27(1582) \\
(0.5-2.0)\end{array}$ \\
\hline $\mathrm{CD} 8, \%($ cells $/ \mu \mathrm{L})$ & $\begin{array}{l}21(4809) \\
(0.4-4.1)\end{array}$ & $\begin{array}{l}27(3780) \\
(0.2-1.8)\end{array}$ & $\begin{array}{l}29(3691) \\
(0.2-1.7)\end{array}$ & $\begin{array}{l}30 \\
(0.3-1.3)\end{array}$ & $\begin{array}{l}27 \\
(0.2-1.2)\end{array}$ & $\begin{array}{l}29(1699) \\
(0.2-1.2)\end{array}$ \\
\hline $\begin{array}{l}\text { CD16+CD56+, \% } \\
(\text { cells } / \mu \mathrm{L})\end{array}$ & $\begin{array}{l}<1 \\
(0.071-3.5)\end{array}$ & $\begin{array}{l}10(1400) \\
(0.061-0.51)\end{array}$ & $\begin{array}{l}12(1527) \\
(0.070-0.59)\end{array}$ & $\begin{array}{l}3 \\
(0.092-1.2)\end{array}$ & $\begin{array}{l}6 \\
(0.10-1.2)\end{array}$ & $\begin{array}{l}19(1113) \\
(0.10-1.2)\end{array}$ \\
\hline $\mathrm{CD} 19, \%($ cells $/ \mu \mathrm{L})$ & $\begin{array}{l}28(6412) \\
0.94 \\
\quad(0.11-7.7)\end{array}$ & $\begin{array}{l}19(2660) \\
(0.18-1.3)\end{array}$ & $\begin{array}{l}17(2164) \\
(0.10-0.80)\end{array}$ & $\begin{array}{l}22 \\
(0.12-0.74)\end{array}$ & $\begin{array}{l}22 \\
(0.064-0.82)\end{array}$ & $\begin{array}{l}15(879) \\
(0.064-0.82)\end{array}$ \\
\hline $\mathrm{CD} 45 \mathrm{RO} / \mathrm{CD} 4, \%$ & 1 & 21 & 20 & 17 & 56 & 48 \\
\hline $\mathrm{CD} 45 \mathrm{RO} / \mathrm{CD} 8, \%$ & 0 & 28 & 22 & 10 & 53 & 52 \\
\hline CD45 RA/CD4, \% & 92 & 79 & 80 & 83 & 54 & 52 \\
\hline CD45 RA/CD8, \% & 97 & 72 & 78 & 90 & 57 & 48 \\
\hline $\mathrm{TCR} \alpha / \beta / \mathrm{CD} 3$ & $\begin{array}{l}99 \\
(46-88)\end{array}$ & ND & ND & ND & $\begin{array}{l}94 \\
(36-98)\end{array}$ & $\begin{array}{l}79.5 \\
(36-98)\end{array}$ \\
\hline $\mathrm{TCR} \gamma / \delta / \mathrm{CD} 3$ & $(1-10)$ & ND & ND & ND & $\begin{array}{l}4 \\
(0.83-11)\end{array}$ & $\begin{array}{l}18.5 \\
(0.83-11)\end{array}$ \\
\hline \multicolumn{7}{|l|}{ B phenotype, \% of CD19+ } \\
\hline Memory B cells & & & $\begin{array}{l}3.4 \\
(18.6-46.7)\end{array}$ & $\begin{array}{l}3.5 \\
(13.3-47.9)\end{array}$ & $\begin{array}{l}3.4 \\
(17.5-46.5)\end{array}$ & $\begin{array}{l}2.3 \\
(17.5-46.5)\end{array}$ \\
\hline Naive B cells & & & $\begin{array}{l}96.6 \\
(47.3-77.0)\end{array}$ & $\begin{array}{l}96.5 \\
(51.3-82.5)\end{array}$ & $\begin{array}{l}96.6 \\
(48.4-79.7)\end{array}$ & $\begin{array}{l}97.7 \\
(48.4-79.7)\end{array}$ \\
\hline Transitional & & & $\begin{array}{l}3.4 \\
(4.6-8.3)\end{array}$ & $\begin{array}{l}2 \\
(0.83-11)\end{array}$ & $\begin{array}{l}2 \\
(0.9-5.7)\end{array}$ & $\begin{array}{l}2.6 \\
(0.9-5.7)\end{array}$ \\
\hline \multicolumn{7}{|c|}{ Lymphocyte proliferative function, $10^{3} \mathrm{cpm} \S$} \\
\hline PHA (NV > 50) & 204 & 76 & 36 & ND & 80 & 17 \\
\hline OKT3 (NV > 20) & 1 & 40 & 11 & ND & 35 & 24 \\
\hline Candidin (NV > 10) & 1 & 45 & 13 & ND & ND & ND \\
\hline Tetanus toxoid $(\mathrm{NV}>10)$ & 1 & 119 & 6 & ND & ND & ND \\
\hline \multicolumn{7}{|l|}{ Chimerism (FISH) } \\
\hline Blood & & $100 \%$ donor & $100 \%$ donor & $100 \%$ donor & $100 \%$ donor & $100 \%$ donor \\
\hline Lymphocytes & & ND & $100 \%$ donor & $100 \%$ donor & $100 \%$ donor & $100 \%$ donor \\
\hline $\mathrm{CD} 3+$ & & & $100 \%$ & $100 \%$ & $100 \%$ & $100 \%$ \\
\hline CD19+ & & & $100 \%$ & $100 \%$ & $100 \%$ & $100 \%$ \\
\hline CD16 + CD56+ & & & $100 \%$ & $100 \%$ & $100 \%$ & $100 \%$ \\
\hline CD14+ & & ND & $100 \%$ donor & $100 \%$ donor & $100 \%$ donor & $100 \%$ donor \\
\hline
\end{tabular}

WBC white blood cells; ND not done; TCR T cell receptor; PHA phyto hemagglutinin; FISH fluorescence in situ hybridization; serum immunoglobulin concentrations from Aksu G et al., Turk J Pediatr. 2006; T cell subsets from Schatorje E. J. H. et al., Clin Immunol 2011; B cell subsets from Piatosa B et al., Cytometry Part B (Clinical Cytometry) 2010

*Under monthly IVIG infusion

§The normal value indicated was measured in the same experiment when two controls were used for allogeneic stimulation

${ }^{\wedge} \mathrm{CD} 3$ gated on CD4: - CD3+CD4+ CD27+CD45RA+ 55.9\%; CD4+ CD31+ CD45RA+ 46.5\%; CD3+CD4+CD27-CD45RA+ 2.7\%; CD3+CD4+ CD27-CD45RA- 5.8\%; CD3+CD4+CD27+CD45RA- 35.4\%. Gated on CD8: CD3+CD8+CCR7+CD45RA+ 31.7\%; CD3+CD8+CCR7+CD45RA$1.67 \%$; CD3+CD8+CCR7-CD45RA- 44\%; CD3+CD8+CCR7-CD45RA+ 22.8\% 
immunological alterations will persist. Hypomorphic mutations of the $I K B K G$ gene encoding the nuclear factor $\mathrm{kB}$ essential modulator (NEMO) protein, a key regulator of the canonical NF-KB signaling pathway, lead to X-linked recessive ectodermal dysplasia with immunodeficiency (XR-EDAID). As in NFKBIA patients, HSCT represents the cure for the most life-threatening clinical manifestations; however, even in XR-EDA-ID, non-hematopoietic manifestations such as colitis did not appear to be solved after HSCT and together with preexisting mycobacterial infection seem to represent the major factors of a poor outcome. Indeed, the persistence of impaired NF-kB signaling in bone marrow stromal microenvironment and in extra-hematopoietic tissues and the lack of normal development of secondary lymphoid organs limits the restoration of a complete innate and adaptive immunological response. Thus, these patients need a specific follow-up for potential complications related both to a partially functional immune system and to disrupted NF$\mathrm{kB}$ pathway in other cell types not corrected by HSCT as LTO cells involved in the development and maturation of secondary lymphoid tissues. Alternative and/or complementary treatment strategies to correct defective NF-kB pathway in non-hematopoietic cells are needed and would be beneficial in order to obtain a full reconstitution of immune function in patients with NFKBIA deficiency and prevent extra-hematopoietic complications. 11

Acknowledgments The authors are grateful to Dr. Di Cesare, University of Rome Tor Vergata, Dr Alessia Scarselli and Dr. Cascioli, Childrens' Hospital Bambino Gesù, Rome, for their help in providing data. We would like to thank the patient and his family, the nurses, for their participation in this study.

Funding Information The study was supported by grants of the Italian Ministero della Salute (NET-2011-02350069) and the Ricerca Corrente from Childrens' Hospital Bambino Gesù, Rome, Italy (201702P003966) to FC CC.

\section{Compliance with Ethical Standards}

Conflict of Interest The authors declare that they have no conflict of interest.

\section{References}

1. Boisson B, Puel A, Picard C, Casanova J-L. Human IkB $\alpha$ gain of function: a severe and syndromic immunodeficiency. J Clin Immunol. 2017;37(5):397-412.

2. Courtois G, Smahi A, Reichenbach J, Döffinger R, Cancrini C, Bonnet $\mathrm{M}$, et al. A hypermorphic IkappaBalpha mutation is associated with autosomal dominant anhidrotic ectodermal dysplasia and T cell immunodeficiency. J Clin Invest. 2003;112(7):1108-15.

3. Dupuis-Girod S, Cancrini C, Le Deist F, Palma P, Bodemer C, Puel A, et al. Successful allogeneic hemopoietic stem cell transplantation in a child who had anhidrotic ectodermal dysplasia with immunodeficiency. Pediatrics. 2006;118(1):e205-11.

4. Kovanda A, Kocjan BJ, Luzar B, Bravo IG, Poljak M. Characterization of novel cutaneous human papillomavirus genotypes HPV-150 and HPV-151. PLoS ONE . 201125 [cited 2019 Jul 19];6(7). Available from: https://www.ncbi.nlm.nih.gov/pmc/ articles/PMC3143161/.

5. Mooster JL, Le Bras S, Massaad MJ, Jabara H, Yoon J, Galand C, et al. Defective lymphoid organogenesis underlies the immune deficiency caused by a heterozygous S32I mutation in I $\mathrm{B}$ B $\alpha$. J Exp Med. 2015;212(2):185-202.

6. Petersheim D, Massaad MJ, Lee S, Scarselli A, Cancrini C, Moriya $\mathrm{K}$, et al. Mechanisms of genotype-phenotype correlation in autosomal dominant anhidrotic ectodermal dysplasia with immune deficiency. J Allergy Clin Immunol. 2017;17.

7. Laffort C, Le Deist F, Favre M, Caillat-Zucman S, Radford-Weiss I, Debré $\mathrm{M}$, et al. Severe cutaneous papillomavirus disease after haemopoietic stem-cell transplantation in patients with severe combined immune deficiency caused by common gammac cytokine receptor subunit or JAK-3 deficiency. Lancet Lond Engl. 2004;363(9426):2051-4.

8. Nowak K, Linzner D, Thrasher AJ, Lambert PF, Di WL, Burns SO. Absence of $\gamma$-chain in keratinocytes alters chemokine secretion, resulting in reduced immune cell recruitment. J Invest Dermatol. 2017;137(10):2120-30.

9. de Jong SJ, Créquer A, Matos I, Hum D, Gunasekharan V, Lorenzo $\mathrm{L}$, et al. The human CIB1-EVER1-EVER2 complex governs keratinocyte-intrinsic immunity to $\beta$-papillomaviruses. J Exp Med. 2018;215(9):2289-310.

10. Zhang Q, Lenardo MJ, Baltimore D. 30 years of NF-kB: a blossoming of relevance to human pathobiology. Cell. 2017;168(1-2):37-57.

Publisher's Note Springer Nature remains neutral with regard to jurisdictional claims in published maps and institutional affiliations. 